\title{
CORRIGENDA
}

\section{Acholeplasma laidlawii Cells Acutely and Chronically Infected with Group 1 Acholeplasmavirus}

\author{
By ALAN LISS AND BRENDA E. RITTER \\ Journal of General Microbiology (1985), 131, 1713-1718
}

p. 1714, last paragraph of Methods:

The second sentence should read: 'Polypeptide profiles of these cell preparations were obtained by SDS-PAGE (Liss \& Heiland, 1982), modified by using glass-distilled water instead of 8 Murea in the formulation of the separating gel and the sample preparation solution'.

\section{Dimorphism in Candida albicans: Contribution of Mannoproteins to the Architecture of Yeast and Mycelial Cell Walls}

\author{
By M. VICTORIA ELORZA, AMELIA MURGUI AND \\ RAFAEL SENTANDREU
}

Journal of General Microbiology (1985), 131, 2209-2216

p. 2211:

The heading has been omitted from the Table at the foot of the page. It should read 'Table 1 . Solubilization of wall mannoproteins of C. albicans with different agents'.

\section{Stimulation of Sexual Reproduction of Phytophthora cactorum by Phospholipids}

\author{
By W. H. KO
}

Journal of General Microbiology (1985), 131, 2591-2594

p. 2591, second paragraph of Methods:

The second sentence should read 'The following trace elements were supplied per litre: FeEDTA, $100 \mathrm{mg}$; $\mathrm{CuSO}_{4} .5 \mathrm{H}_{2} \mathrm{O}, 10 \mathrm{mg} ; \mathrm{MnCl}_{2} .4 \mathrm{H}_{2} \mathrm{O}, 10 \mathrm{mg} ; \mathrm{Na}_{2} \mathrm{MoO}_{4} .2 \mathrm{H}_{2} \mathrm{O}, 5 \mathrm{mg}$; $\mathrm{Na}_{2} \mathrm{~B}_{4} \mathrm{O}_{7} .10 \mathrm{H}_{2} \mathrm{O}, 10 \mathrm{mg}$; $\mathrm{ZnSO}_{4} .7 \mathrm{H}_{2} \mathrm{O}, 10 \mathrm{mg}$; thiamin hydrochloride, $100 \mathrm{mg}$.' 